\title{
GAMBARAN DIRI ANDREA HIRATA DALAM NOVEL EDENSOR: KONSEP TRAVEL WRITING CARL THOMPSON
}

\author{
Arie Azhari Nasution \\ Sastra Indonesia Universitas Sumatera Utara, Medan \\ E-mail: arieazharinst@gmail.com
}

\begin{abstract}
Abstrak
Pokok bahasan dalam penelitian iniadalah menelaah gambaran diri Andrea Hirata dalam novelnya, Edensor, yang bercerita tentang perjalanannya mengelilingi Eropa dan sebagian negara Afrika sebagai bentuk travel writing. Untuk menemukan bagaimana Andrea Hirata menulis dan menggambarkan ruang-ruang yang ditemukannya sebagai bentuk laporan dari tempat yang ia kunjungidan bagaimana ia memposisikan dirinya sebagai seorang traveler, digunakan teori travel writing Carl Thompson dengan mengidentifikasi novel Edensor dari konsepReporting The World, Revealing The Self, dan Representing The Other. Hasilnya, Andrea Hirata yang teridentifkasi sebagai romantic traveller cenderung memberi gambaran dirinya secara autobiografi dan lebih kepada kesadaran diri (self-consciously) yang ditampilkan dalam setiap perjalanan dikarenakan motivasi yang dibuat guna menemukan dirinya. Selain itu, ia mengakui dirinya sebagai yang inferior terhadap Barat karena berasal dari Timur.
\end{abstract}

Kata kunci: Andrea Hirata, Edensor, Travel Writing, Pascakolonial,Perjalanan, Gambaran Diri.

\section{Abstract}

This research is about to review the self-image in the novel by Andrea Hirata, Edensor, which tells the story of his travels around Europe and some African countries as a form of travel writing. To discover how Andrea Hirata write and illustrate the discovery of spaces as a form of a report from the places he visited and how he positioned bimself as a traveler, used the theory of travel writing Carl Thompson to identify novel Edensor from concept Reporting The World, Revealing The Self, and Representing The Other. As a result, Andrea Hirata identified as a romantic traveler who tends to give a picture of himsel fas an autobiography and more to self-awareness (self-consciously) displayed in each trip made because the motivation to find himself. Moreover, he recognizes himself as inferior to the West because he comes from the East.

Keywords: Andrea Hirata, Edensor, Travel Writing, Postcolonial Studies, Travel, Self-Image.

\section{Pendahuluan}

Perjalanan manusia mengarungi dunia telah dimulai berabad-abad lalu. Dalam perjalanannya, manusia selalu menemukan ruang-ruang baru sebagai hal yang baru, terutama bagi orang-orang yang melakukan perjalanan tersebut. Selainitu,mereka tentu menghadapi perbedaan dan keberbedaanyang merupakan sebuah konfrontasi atau negosiasiyang kompleks dari apa yang disebut alteritas dan identitas, perbedaan dan persamaan. Sehingga dapat dikatakan bahwa perjalanan merupakan sebuah negosiasi antara diri (self) dan yang lain (other) disebabkan oleh pergerakan melaluiruang dan waktu.

Seiring berkembangnya zaman, orang-orang yang melakukan perjalanan, berhasrat menuliskan kisah perjalanannya dan menggambarkan seluruh keadaan tempat dimana ia pernah singgah. Catatan dari hasil perjalanan tersebut kebanyakan menawarkan sebuah narasi dari peristiwa-peristiwa yang terjadi selama perjalanan penulisnya. Tidak jarang pula catatan perjalanan tersebut memberikan sebuah laporan baru dari perspektif penulisnya, sebuah pengalaman pribadi dari penulis. Tentunya, tidak semua pergerakan perjalanan ditulissecara detailoleh orang yang melakukan perjalanan, melainkan hanya pergerakan-pergerakan yang menurutnya menarik dan berkesan yang dituliskannya ke dalam catatan perjalanannya sebagai bentuk translasi dari travel experience ke dalam travel text. Kisah-kisah perjalanan inilah yang kemudian dijadikan sebuah bukuyang dikenal dengan jenis travel writing. 
Travel writing adalah segala catatan yang merekam pertemuan antara diri (self) dan yang lain (other), dan negosiasi-negosiasi atas perbedaan atau persamaan yang melingkupinya. Definisi ini tentu bukan definisi final dari apa yang disebut travel writing.Para kritikus dan akademisi menggunakan label 'travel writing' dalam arti yang lebih luas dan inklusif, jadi, tidak hanya publikasi yang berhubungan dengan perjalanan saja yang diuraikan, tetapi juga bentuk dokumen lain yang berhubungan dengan perjalanan atau artefak kebudayaan (Thompson, 2011:10-13).

Di Indonesia, telah banyak tulisantulisan yang dapat diasumsikan sebagai tulisan bergenre travel writing. Salah satunya adalah Andrea Hirata yang terkenal sebagai penulis novel tetralogi Laskar Pelangi (Laskar Pelangi (2005), Sang Pemimpi (2006), Edensor (2007), dan Maryamah Karpov (2008). Novel Edensor (2007) dalam tetralogi yang ditulis Andrea Hirata merupakan sebuah karya perjalanan penulisnya pada saat menempuh kuliah di Sorbonne, Prancis dan merupakan novel yang dapat dianggap sebagai novel pendahulu bergenre travel writing awal di Indonesia pada dekade 2000an (sebelum diikuti novel bergenre sama seperti Garis Batas:Perjalanan di Negeri-Negeri Asia Tengah (2011) oleh Agustinus Wibowo atau 99 Cahaya di Langit Eropa (2011), Bulan Terbelah di Langit Amerika (2014) karya Hanum Salsabiela Rais dan Rangga Almahendra, dan lainnya.)

Novel Edensor menceritakan petualangan Ikal dan Arai mulai dari impian mereka di Indonesia yang suatu hari akan pergi ke sekolah di Perancis dan cita-cita mereka tersebut akhirnya tercapai. Di Perancis, sambil kuliah, Ikal dan Arai melakukan perjalanan keliling Eropa dan sebagian negara di Afrika. Perjalanan yang dilakukan Ikal dan Arai ini, selain mewujudkan mimpi mereka sejak kecil, merupakan sebuah pencarian diri dan cinta. Dari perjalanan yang dilakukan Ikal dan Arai dalam novel tersebut, maka penelitian terhadap novel ini akan dilakukan menggunakan teori Travel
Writing Carl Thomson untuk mengidentifikasi bentuk gambaran diri Andrea Hirata sebagai penulis novel.

Dalam Travel Writing, Carl Tompson (2011) mengemukakan beberapa pokok persoalan untuk mengidentifikasi tulisan 'travel writing' sebagai sebuah genre tulisan. Dimulai dari gambaran ikhtisar dari evolusi 'travel writing'(dari Western travel writing) periode kuno sampai dengan saat ini, strategi penulis yang bermacam-macam untuk menyampaikan tulisannya dan pembaca yang menduga kebenaran dalam travel writing (Reporting The World), aspek autobiografi dalam travel writing dan subjektivitas penulis (Revealing The Self), implikasi pokok travel writing yang menawarkan gambaran dan representasi dari orang lain dan budaya yang lain (Representing The Other), sampai kepada isu mengenai gender dan seksualitas dalam perjalanan dan travel writing.

\section{Reporting The World}

Apabila dikategorikan sesuai dengan periode travel writing yang dikemukakan Carl Thompson, Novel Edensor dapat dikategorikan pada periode travel writing from 1914 to the present. Travel writing, apapun bentuknya, tujuan utamanya adalah membawa sebuah berita dari dunia yang luas dan menyebarkan informasi tentang orang-orang dan tempat yang belum dikenal. Namun demikian, ketika gambaran sebuah dunia dituliskan, ia mengalami perubahan dari pengalaman perjalanan menjadi teks perjalanan sehingga akurasi dan objektivitas memberikan pengaruh pada penggambaran tempat tersebut sehingga jauh dari realitas yang kompleks. Secara esensial, catatan perjalan merupakan fiksi dari representasi yang faktual (Thompson, 2011: 63).

Dalam novel Edensor, gambaran cerita perjalanan disampaikan dengan sudut pandang orang pertama sebagai narator yakni 'aku' sebagai tokoh Ikal (yang juga merupakan suara penulis novel, Andrea Hirata) sehingga gambaran yang diberikan tentang suatu 
tempat merupakan pernyataan seseorang yang benar-benar hadir di dalam tempat yang digambarkan. Perbedaan-perbedaan yang diberikan merupakan bagian dari negosiasi dan subjektivitas Andrea Hirata sebagai penulis dalam menulis dan menggambarkan apa yang sebenarnya dialaminya pada saat berada di tempat tersebut. Penggunaan berbagai gaya bahasa dalam menulis mempengaruhi penggambaran pada suatu objek. Bahasa kiasan dan perbandingan dalam penulisan catatan perjalanan mampu membuat seseorang seakanakan berada pada tempat yang dikunjungi traveler, dari yang sebelumnya sebagai tempat yang tidak dikenal, menjadi dikenali.

"Kami meninggalkan gedung yang tak bersahabat itu, terseok memanggul ransel dan menyeret koper butut yang berat, tak keruan tujuan, yang ada dalam pikiran hanya bagaimana menyelamatkan diri dari sengatan dingin. Dalam rumah-rumah persegi berjendela kaca, orang berkerumun di ruang tamu, mengelilingi pohon natal, temaram, bersenda gurau, tak mau jauh dari jangkauan pemanas. Di sini tak bisa sembarang mengetuk pintu rumah orang. Pengalaman dengan Van Der Wall sedikit banyak mengajari kami, dan kami belum melapor pada pihak berwenang. Mengetuk pintu dalam keadaan seperti itu sangat mungkin berurusan dengan hukum. Motel tak tampak. Brugge sama sekali bukan tujuan wisata" (Hirata, 2008:61).

Dari kutipan di atas, tampak subjektivitas penulis sebagai orang yang mengalami sendiri bagaimana kondisi yang dialaminya saat di Brugge. Ia menggambarkan situasi yang keadaan sekitar berdasarkan apa yang ia lihat dan memasukkan pendapatnya berdasarkan pengalaman yang telah didapat sebelumnya. Ketidaktahuannya akan budaya dan situasi tempat di mana tokoh (Ikal dan Arai) berada, sehingga mereka tidak tahu apa yang harus dilakukan karena cuaca di Brugge yang dingin. Mereka melihat orang sekitar yang tidak mempedulikan keadaan di luar, dan tidak ada motel untuk bisa ditempati saat malam, sehingga penulis melaporkan isi pikirannya bahwa Brugge bukan tujuan wisata.

"Dari buku Collins World Atlas aku melihat Brugge tepat berada di sisi North Sea (Laut Utara), laut terdingin yang disarankan untuk dihindari selama winter (musim salju), karena dinginnya berbahaya. Laut Utara adalah mainstream laut es Artik di Kutub Utara. Jika winter tiba, bahkan burungburung red knox di Brugge melarikan diri ke pantai-pantai Italia. Di ujung Jalan Oudlaan kami menemukan bangku taman. Kami duduk di bawah naungan kanopi. Hujan salju makin lebat. Sunyi, mencekam. Desis angin berubah menjadi seribu mata lembing, menghujam tubuh kami yang lapar dan kedinginan. Seumur hidup dijerang suhu dalam kisaran tiga puluh empat derajat celcius, bahkan baru sehari yang lalu di Belitong kami bermandi panas tiga puluh sembilan derajat, kini kami menghadapi suhu yang bisa jatuh sampai minus" (Hirata, 2008:62).

Selain subjektivitas, penambahan referensi, baik ilmiah maupun data-data informasi terdahulu mengenai suatu tempat atau budaya akan memperkaya hasil tulisan. Pada kutipan di atas, Ikal membawa buku Collins World Atlasyang merupakan buku referensi yang ia gunakan untuk membantu perjalanannya di Eropa. Lalu ia menggambarkan suasana yang sedang dialaminya dan membandingkannya dengan tempat sebelumnyadimana ia berasal. Ia juga mengomentari keadaan sekitar sehingga pembaca seakan-akan mengetahui gambaran situasi yang sedang dihadapinya. Kutipan di atas dapat juga dikategorikan seperti apa yang dikemukakan Rob Nixon sebagai 'semiethnographic. Dengan demikian, validitas tentang penggambaran suatu tempat tidak hanya didasarkan pada sisi subjektivitas penulis dan terkesan dari pengalaman penulis sendiri. Dengan memberikan gambaran yang objektif berupa fakta tentang sesuatu yang dilihat 
dan dirasakan,memberikan efek yang lebih nyata ketika mengunjungi suatu tempat dalam perjalanan.

Penggambaran dunia lainnya adalahkombinasi dari subjektivitas penulis, pengungkapan dengan gaya bahasa, dan juga analisis terhadap apa yang dilihat secara emosional. Laporan perjalanan yang dikombinasikan seperti demikian, banyak dituliskan dalam novel Edensor. Hal ini senada dengan apa yang dikemukakan Rob Nixon (dalam Thompson, 2011: 87) "we typically find in travel literature today an oscillation between 'an autobiographical, emotionally tangled mode' and a 'semiethnographic', distanced, analytical mode". Contohnya terdapat pada kutipan berikut.

"Hebat sekali kantor Uni Eropa, meraja di jantung kota Brussel, kukuh berwibawa melambangkan supremasi bangsa-bangsa Eropa. Arsitektur dasarnya seperti kuburan juragan kaya Tionghoa, seperti tubuh yang ingin memeluk. Maksud desain itu bukan hanya soal estetika, namun lengan-lengan yang merengkuh taman berlantai granit itu adalah rancangan untuk berlindung dari guncangan bom. Selain sebagai lambang digdaya, gedung Uni Eropa juga metafor paranoia, penyakit kronis orang Barat" (Hirata, 2008:67).

Kutipan di atas merupakan laporan penulis tentang kantor Uni Eropa yang dilihatnya di kota Brussel. Dengan memadukan gaya bahasa pada pendapatnya tentang kantor tersebut, ia juga menganalisis gedung tersebut dengan berbagai kiasan dengan maksud ingin menunjukkan bahwa gedung tersebut terlihat sangat megah dan kokoh.

Narasi-narasi yang terdapat dalam novel Edensor kebanyakan merupakan narasi personal dari perjalanan seorang traveler. Narasi-narasi yang dihadirkan selalu memberikan informasi tertentu tentang alur perjalan Ikal dan Arai sebagai traveler.

"Sekonyong-konyong, nasib kami berbalik di negeri Balkan. Orangorang Balkan (Bosnia, Serbia, dan sekitarnya), korban perang itu, jangankan mengapresiasi seni, bahkan masih trauma akan peluru yang baru saja reda berdesing di atas kepala mereka. Secepat kehancuran Yugoslavia, sesegera itulah kami kembali jatuh miskin. Kacamata ray ban-ku, celana kordurai, jaket bulu Arai, sepatu koboinya, semuanya harus tergadai atau dibeli setengah paksa oleh manusia-manusia setengah tentara setengah preman kaum rebel, reneqede, para oportunis perang demi setangkup roti. Pohon plum jarang tumbuh di Balkan sehingga kami tak dapat menjadi herbivora dengan menggasak daun-daunnya. Di perempatanperempatan jalan di Macedonia, kami menunggu mobil salvation army utusan gereja. Para pengikut Kristus yang taat itu setiap malam berkeliling kota membawa dandang besar berisi sup kacang merah. Mereka memberi makan para gelandangan, tanpa peduli gelandangan itu katholik, protestan, mormon, baptis, agnostik, atheis, budha, muslim, komunis, demokrat, republikan, homo, lesbian, transeks, hetero, atau penjahat. Mobil bala keselamatan berkeliling kota setiap pukul sebelas malam. Jika kami berpuasa sunnah, maka kacang merah pukul sebelas malam itu adalah buka puasa sekaligus sahur kami untuk puasa esoknya" (Hirata, 2008:217).

Padakutipan diatas, penulis memberikan kesan subjektifnya terhadap keadaan yang ia alami. Selain menggambarkan keadaan fisik Ikal dan Arai, juga menggambarkan situasi keadaan tempat yang tengah dialui dan gambaran yang akan terjadi berikutnya sebagai refleksi dari perjalanan sebelumnya. Keadaan Ikal dan Arai sebelumnya cukup kaya karena hasil mengamen di negara sebelum mereka ke Balkan.Masyarakat Balkan sama sekali tidak mengapresiasi seni dan masih trauma terhadap perang yang sebelumnya mereka alami. Hal tersebut membuat Ikal dan Arai kembali miskin karena tidak mendapatkan uang saat mengamen di sana sehingga mereka menjual segala benda yang ada di tubuh mereka 
demi makanan, bahkan mereka menjadi seperti gelandangan dan kelaparan. Dalam kutipan narasi di atas juga memberikan laporan sebuah keadaan moral dari suatu bangsa, mulai dari yang buruk (dibeli setengah paksa oleh manusiamanusia setengah tentara setengah preman kaum rebel, reneqede) sampai pada keadaan moral yang baik (Mereka memberi makan para gelandangan, tanpa peduli gelandangan itu...)

\section{Revealing The Self}

Perjalanan Ikal dan Arai ke luar negeri di mulai pada bab (atau seperti yang disebut dalam novel: mozaik)10, yaitu Curly. Subjektivitas narator telah tampak dalam penggambaran penjelajahan dan pelaporan dunia. Narator mengikutsertakan dirinya dalam memandang situasi, keadaan, kondisi dunia tempat ia berada dengan banyak mengomentari apa yang dilihatnya dalam perjalanan. Seperti yang diungkapkan Thompson, "At its most extreme, this tendency in the genre has led totravelogues that are almost wholly about the traveller-narrator rather than the places visited, as the encounter with the wider worldbecomes merely a pretext or prompt to narratorial introspection andself-analysis" (Thompson, 2011: 98).

Andrea Hirata pada bagian ini cenderung memberi gambaran dirinya sendiri dalam perjalanan bahkan mencoba untuk menemukan dirinya sendiri dalam perjalanannya yang kemudian dituangkannya ke dalam novelnya. Dalam hal ini, kesubjektivitasan penulisan lebih ditekankan dalam menggambarkan perjalanan yang dilaluinya. Sehingga dengan ini, Andrea Hirata banyak menggambarkan dirinya ke dalam novelnya melalui penggambaran yang ditulis dari tempat yang dikunjungi. Ia bahkan mendramatisasi perlakuan dalam menggambarkan sesuatu, sehingga pembaca seperti merasakan pengalaman yang dialaminya. Seperti pada kutipan berikut.

"Masih dalam lingkar pemanas Bandara Schippol, kami tak menyadari kalau suhu dingin di luar seganas gigitan hewan buas. Kami celingukan mencari wanita gemuk petugas administrasi itu. Pasti ia berdiri di sana, di antara para penjemput, sambil memegang 43 benda semacam bat pingpong dengan tulisan dari tinta emas: Mr.Andrea Hirata and Mr. Arai Ichsanul Mahidin, welcome to Holland. Namun, tak ada tanda semacam itu. Yang ada hanya gadismuda berandal yang berteriak-teriak tak keruan ini. "Oiiik! Oiiik! Oiiiiik,keke!"

Ia berlari-lari menuju kami, kami terkejut, menoleh kiri-kanan, siapakah dia! Ia pasti salah mengenali orang.

“Oiiik!! Oiiik! Oiiiikke!!” Tapi memang kami yang dipanggilnya. Aneh. Kami berhenti, ia megap-megap.

"Waithbhh..." dengusnya. Ia membungkuk, keringatnya bersimbah, dadanya kembang kempis. Lalu ia tegak lagi, bertelakan pinggang sambil mengatur napas. Kami masih mematung. Bingung.Siapakah gadis berandal ini? Ia sangat jangkung, 180 senti mungkin. Atletis, padat berisi. Tubuhnya dibangun kerangka Kaukasia yang sempurna. Ia mengenakan shapely tank top. Perutnya kelihatan dan pasti dia sering sit up. Rambutnya berantakan, pirang menyala-nyala. Belakangan kami tahu, oik adalah cara orang Belanda menyebut bai" (Hirata, 2008:52-53).

Selain itu, tak jarang Andrea menaburkan metafora-metafora dalam laporan perjalanannya agar dapat dibaca sebagai hasil karya yang indah. Detail-detail gerakanpun tak luput dari perhatian Andrea dalam menggambarkan perjalanannya. Dari kutipan di atas diketahui juga bahwa Andrea tidak hanya menginformasikan gambaran dari situasi dunia di sekitarnya tetapi juga interaksi antara self (dirinya) dengan other (F. Somers). Selain itu, kutipan di atas memberikan gambaran tentang kesan subjektif pikiran dan perasaan pribadi Andrea. Hal tersebut juga dapat dilihat pada kutipan berikut. 
"Bus melaju, sopirnya saksama menyiasati jalan bersalju. Meretas ke selatan, kami melewati tempat-tempat yang semakin lama semakinPrancis: Liege, Marche, Bastogne. Rumahrumah penduduk sepi menyendiri dan pertanyaan mengerumuniku: bagaimana kota-kota itu jatuh dan bangun dalam masa perang Eropa? Bagaimana rasanya berada dalam tarikmenarik budaya Belanda dan Prancis? Bahasa apa yang mereka pakai? Mengapa bahasa bisa berbeda padahal hanya terpisah sejauh tetangga? Inikah akibat kutukan seribu bahasa dari Tuhan pada kaum hedonis Babylonia, karena telah kurang ajar membangun tangga menuju surga? Apakah Njoo Xian Ling tersembunyi di salah satu rumah yang temaram itu?" (Hirata, 2008:76).

Dari kutipan di atas selain kesan, pikiran, dan perasaan pribadi Andrea, ia menyelipkan tentang sebuah kenangan yang diasosiasikan dengan perjalanan tersebut, sebuah pencarian akan cintanya kepada seorang perempuan bernama Njoo Xian Ling atau biasa dipanggil A Ling. Hal ini jugalah yang membuat Andrea termotivasi untuk mengelilingi Eropa dan sebagian Afrika, yakni ia mencari wanita yang membuatnya jatuh hati sejak kecil itu.

\begin{abstract}
"Aku kembali ke Paris dalam keadaan frustrasi. Barangkali aku telah melakukan hal-hal yang tak masuk akal. Tapi hanya itu yang dapat kulakukan untuk melipur rinduku, selain membaca novelSeandainya Mereka Bisa Bicara karya Herriot, kenangan A Ling untukku. A Ling menandai cerita tentang keindahan Desa Edensor dalam novel itu. Kubaca bagian itu berulang-ulang. Desa khayalan Edensor itu seakan membuka jalan rahasia dalam kepalaku, jalan menuju penaklukan-penaklukan terbesar dalam hidupku, untuk menemukan A Ling, untuk menemukan diriku sendiri" (Hirata, 2008: 162-163).
\end{abstract}

Secera eksplisit, kisah perjalanan Andrea ini menggunakan autobiografi dirinya dan sebagai sarana penemuan jati dirinya. Senada dengan apa yang dikemukakan Thompson, "In some travelogues, then, the journey functions to some extent as a narrative device whereby the author's whole life may be brought into focus. Many travelogues of this type also present the journey as a key stimulus to a new understanding of the traveller's life" (Thompson, 2011:114).Hal demikian juga dapat dilihat pada kutipan berikut.
"Berkelana tidak hanya telah membawaku ke tempat-tempat yang spektakuler sehingga aku terpaku, tak pula hanya memberiku tantangan ganas yang menghadapkanku pada keputusan hitam putih, sehingga aku memahami manusia seperti apa aku Ini. Pengembaraan ternyata memiliki paru-parunya sendiri, yang dipompa oleh kemampuan menghitung setiap risiko, berpikir tiga langkah ke depan sebelum langkah pertama diambil, integritas yang tak dapat ditawar-tawar dalam keadaan apa pun, toleransi, dan daya tahan. Semua itu lebih dari cukup untuk mengubah mentalitas manusia yang paling bebal sekalipun. Para sufi dan mahasiswa filsafat barangkali melihatnya sebagai hikmah komunikasi transendental dengan Sang Maha Pencipta melalui pencarian diri sendiri dengan menerobos sekat- sekat agama dan budaya. Aku dan Arai menyebutnya sebagai: itulah akibatnya kalau berani-berani bepergian sebagai pengamen!” (Hirata, 2008:229-230).

Lain dari pada itu, dalam novel Edensor juga hadir karena sebuah motivasi perjalanan yang membawa diri penulisnya menemukan dirinya. Setelah pencariannya kemana-mana di Eropa dan sebagian Afrika, Ikal juga tak menemukan A Ling, pujaan hatinya, hingga pada suatu kali saat pencarian berlangsung di Zaire, Afrika, dituliskan sebuah peristiwa yang membuat Ikal memahami kehidupan dan dirinya.

"Suster Nadine menyampaikan satu kalimat bijak untukku, "Kamu telah mencari A Ling demikian jauh sampai 
ke Zaire, di tengah-tengah Afrika, dan tak kautemukan. Tidakkah kau berpikir kau telah menemukannya?"

Aku terhenyak. Tiba-tiba ucapan Roxane Ling dan Suster Nadine terangkai dalam kepalaku menjadi sebuah filosofi pencarian, pencarian akan hal-hal yang paling kita inginkan dalam hidup ini dan pencarian akan diri kita sendiri. Maksud Roxane Ling dan Suster Nadine sama sekali tak seharfiah kalimat mereka. Karena jika kita berupaya sekuat tenaga menemukan sesuatu, dan pada titik akhir upaya itu hasilnya masih nihil, maka sebenarnya kita telah menemukan apa yang kita cari dalam diri kita sendiri, yakni kenyataan, kenyataan yang harus dihadapi, sepahit apa pun keadaannya" (Hirata, 2008: 268-269).

Dari kutipan-kutipan di atas, dapat diidentifikasi bahwa Andrea sebagai penulis travel writing menerapkan ciri penulisan Romantic Traveler.Pertemuannya dengan Suster Nadine membuat ikal sadar akan apa yang sebenarnya dicari selama ini. Pencarian akan cintanya membuat Ikal menemukan dirinya sendiri. Kenyataan-kenyataan dalam perjalanan yang dilakukannya selama ini merupakan sebuah pelajaran dalam hidupnya.

\section{Representing The Other}

Adanya istilah 'other'dalam travel writing merupakan salah satu bentuk identifikasi perbedaan antara satu budaya dengan budaya yang lainnya. Baik pada budaya yang sama maupun pada budaya lainnyatidak hanya menggambarkan perbedaan tetapi juga masalah inferioritas budaya tertentu. Lebih lanjut, dimensi ideologi dalam travel writing secara retoris cenderung bermaksud untuk menciptakan ruang permusuhan dan merendahkan kelompok atau budaya 'other'. Isu ini lebih lanjut berhubungan dengan kajian pascakolonial terutama Orientalisme, Edward Said (Thompson, 2011: 132-134). Di dalam travel writingterkadang terdapat unsur wacana pascakolonial yang merepresentasikan penulis.
Pada novel Edensor, wacana-wacana tersebutdengan sengaja atau tidak-ditulis oleh Andrea Hirata.

Dalam kategorisasi penulis travel writing, Andrea Hirata dapat disebut penulis perjalanan poskolonial pPostcolonial travel writer). Hal ini sejalan dengan apa yang dikemukakan Thompson (2011: 163) ... all travelwriting produced from the late 1960s onward is 'postcolonial', whatever the cultural or ethnic heritage of the travelle;(Semua travel writing yang diproduksi mulai dari tahun 1960-an adalah adalah 'poskolonial', apapun kebudayaan dan etnis dari traveler tersebut). Label ini diberikan kepada para penulis tersebut karena penulisan catatan perjalanan mereka memiliki semacam karakteristik yang membedakannya dari tulisan penulis berkulit putih yang imperialistik dan eksploitatif.

Ada tiga karakteristik penulis perjalanan poskolonial. Pertama, catatan perjalanan penulis poskolonial berupaya menentang stereotipe dan sikap Barat terhadap budaya atau tempat lain; kedua, perluasan sudut pandang, sejarah, dan hubungan antarbudaya yang kerap diabaikan oleh penulis Barat; ketiga, beberapa penulis perjalanan poskolonial tidak menentang asumsi dan stereotip Barat (Thompson, 2011:164165). Dari ketiga karakteristik tersebut, Andrea memiliki karakteristik yang ketiga, yakni sebagai penulis perjalanan yang menerima asumsi dan stereotip Barat, bahkan ia mengakui keinferioran Timur-dalamhal ini Indonesia. Hal tersebut dapat dilihat pada kutipan berikut.

"Kami membuntutinya menuruni tangga dan memasuki platform kereta underground. Terlepas dari sistem pemanas Bandara Schippol, kami langsung menggigil digigit suhu dingin delapan derajat celcius. Famke tergelak melihat kami gemelutuk. Ia sendiri hanya bercelana jeans ketat bolongbolong dan tank top itu.

"Jangan cemas, Kawan, kita segera naik kereta, nanti di dalam panas lagi," katanya.

Aku takjub melihat gadis Belanda ini. Tak sedikit pun ia kedinginan. Tak 
heran Kumpeni bisa menjajah kita sampai karatan. Dari central station Amsterdam kami naik kereta menuju Brussel. Dalam sekejap, kami akrab dengan Famke. Ia tak berhenti bicara dan kami tak berkedip menatap kecantikannya" (Hirata, 2008:55).

Pertemuan dengan gadis Belanda merupakan sebuah pertemuan dari dua budaya yang berbeda. Gadis Belanda tersebut tidak merasa kedinginan walaupun ia memakai pakaian minim (tank top), sedangkan Ikal dan Arai sudah menggigil kedinginan. Hal ini terjadi karena perbedaan musim dan adaptasi orang-orang Eropa terhadap suhu di negerinya, namun hal tersebut dianggap sebagai sebuah kehebatan dan secara langsung menegasikan dirinya sendiri dengan sebagai negara yang tidak hebat, terjajah oleh kumpeni.

"Kompak betul pasangan itu. Tak heran mereka harmonis hidup bersama tanpa anak selama lima belas tahun. Mereka memenuhi kualifikasi kebahagiaan perkawinan versi Oprah: kesamaan pandangan.

Aneh,mengapa mereka gamang soal sumberdaya?'Titouan adalah fotografer profesional, kontributor Maison de la France, dan Isabelle seorang literary agent yang ternama, tugasnya menilai naskah-naskah sastra, mendesain intellectual framework sebuah diskusi buku, sampai mengurusi beberapa penulis kondang Prancis. Di sisi lain, jaminan sosial sangat bagus bagi warga Prancis. Lalu di tanah air? Kriminalitas mengganas, jaminan sosial amblas, pendapatan per kapita terjun bebas, tapi bayi terus-menerus lahir. Rajin sekali kita beranak. Di Apartemen Mallot kutemukan paradoks pertama" (Hirata, 2008:82).

Kutipan di atas membicarakan tentang permasalahan jaminan sosial di Prancis. Digambarkan bagaimana pekerjaan Mallot (orang Perancis) yang masih gamang dengan sumber daya apabila dia menikah. Berbeda dengan di tanah air (metonimi dari Indonesia) yang digambarkan sebagai negara yang inferior, masih jauh dari jaminan sosial yang ada di Prancis. Hal tersebut diakui secara langsung oleh orang yang berasal dari negara yang selalu menjadi inferior dari negara yang dianggap superior (Perancis).

"Ah, ia sebutkan lagi namanya! Aku senang karena orang Prancis membunyikan $n q$ secara sengau pada setiap akhiran $n$. Morong, begitulah pendengaranku, $\mathrm{Ng}$ sengau itu meyakinkanku bahwa aku benar-benar sedang berada di Prancis,

"Tapi Madame, pasti banyak pintu di sana, Apakah tertempel nama Anda di pintu? Sehingga kami mudah menemukannya? Bagaimana nama Anda tertera di sana?"

"Maurent, Maurent LeBlanch,"

Indah bukan main, Morong LeBlang, sengau, beradab, terpelajar, dan sangat berkelas" (Hirata, 2008: 84).

Kekaguman yang digambarkan pada kutipan di atas jelas sekali sebagai sebuah pengakuan akan kesuperioran Perancis dari segi nama dan pengucapannya yang dianggap beradab, terpelajar, dan sangat berkelas.Tidak hanya itu, Andrea Hirata juga membandingkan dunia pendidikan di Indonesia dengan Perancis, dan mengakui bahwa pendidikan di sana jauh lebih baik dibandingkanIndonesia.

"Sering aku merasa heran. Kawankukawanku The Brits, Yankee, kelompok Jerman, dan Belanda adalah para pub crawler kawakan. Mereka senang bermabuk-mabukan. Tak jarang mereka mabuk mulai Jumat sore dan baru sadar Senin pagi. Sebagian hidup seperti bohemian, mengaitkan anting di hidung, mencandu drugs, musiktrash metal, berorientasi seks ganjil, dan tak pernah terlihat tekun belajar, namun mereka sangat unggul di kelas. Aku yang hidup sesuai dengan tuntunan Dasa Dharma Pramuka, taat pada perintah orangtua, selalu belajar dengan giat dan tak lupa minum susu, jarang dapat melebihi nilai mereka. Dengan ini, kutemukan paradoks 
kedua, dalam diriku sendiri” (Hirata, 2008:111).

"Di Sorbonne, setiap hari aku diracuni ilmu meski aku tak ubahnya anak burung puyuh yang tersuruk-suruk mengejar induk belibis. Universitas ini menawarkan padaku sebuah petualangan intelektualitas dengan kemungkinan-kemungkinan yang amat luas. Setiap hari aku selalu tertantang untuk memacu kreativitas dalam bidang yang kutekuni. Aku menyimak kuliah selama dua jam tapi pengetahuan yang kudapat senilai kuliah satu semester waktu di tanah air. Jika kembali kuanalogikan pengalaman bak cahaya yang melesat-lesat di dalam gerbong seperti eksperimen Einstein itu kini aku menyongsong cahaya ekonometrik, statistik, aljabar, dan falsafah ekonomi, dan Einstein pasti mengatakan aku menyerap begitu banyak pelajaran dalam satuan waktu yang relatif singkat" (Hirata, 2008:129).

\section{Gambaran kecerdasan orang-orang} Barat diakui meski mereka kelihatannya tidak pernah memperlihatkan bahwa mereka pernah belajar, dan secara langsung dinegasikan pada budaya Timur walaupun sudah melakukan segala cara untuk bisa menjadi lebih cerdas dari Barat, tetap saja, tidak bisa dilakukan. Hal ini terlihat ketika orang-orang Barat sebagaimana dijelaskan dengan kehidupan mereka yang bohemian dan tidak pernah terlihat tekun belajar, mereka masih jauh lebih unggul daripada Ikal yang mengibaratkan dirinya sebagai 'burung puyuh yang tersuruk-suruk' yang selalu belajar dan menyimak ketika kuliah.

Tidak jarang pula, di dalam novelnya, Andrea Hirata cenderung lebih mengakui bahwa Indonesia (Timur) memang negara yang inferior, terbelakang, dan tidak beradab, meskipun dibandingkan dengan negara Timur lainnya yakni Jepang.

"Yang paling kusuka dari teater musim panas adalah cerita orangorang kaya baru Asia yang berbelanja ke Paris. Pulang ke tanah air, mereka petantang-petenteng mengaku telah menjelelajahi butik Prada sepanjang L'Avenue des ChampsElysees, padahal hanya memborong baju obral di Mal Lafayette. Namun, yang kutonton berulang-ulang adalah parodi, inspired by a true story, tentang dilema seorang mahasiswa Indonesia di Paris yang menjadi guide bagi para petinggi yang ingin berutang. Parodi ini mencapai klimaks saat para petinggi Jepang, yang memberi utang, datang ke tempat pertemuan dengan mobil mini bus carteran, sedangkan para petinggi Indonesia, yang berutang, datang satu per satu dengan limousine" (Hirata, 2008:147).

Kutipan di atas menggambarkan sebuah laporan mengenai kelakuan-kelakuan orang Indonesia yang mencoba mengidentifikasikan dirinya sebagai orang yang terpandang, namun kebenarannya adalah yang sebaliknya. Terpandang karena menggunakan mobil limosin untuk menemui petinggi Jepang, namun tujuannya adalah meminjam uang kepada petinggi Jepang tersebut yang hanya memakai bus carteran, padahal mereka yang akan memberikan pinjaman. Pengakuan keinferioran diri lebih tampak jelas pada kutipan berikut.

"Aku senang telah mengenal Katya, terutama karena perempuancanggih dari Eropa itu telah memberiku pelajaran moral nomor dua belas yaitu: ke mana pun tempat telah kutempuh, apa pun yang telah kucapai, dan dengan siapa pun aku berhubungan, aku tetaplah seorang lelaki udik, tak dapat kubasuh-basuh" (Hirata, 2008:160).

Ikal mengakui bahwa daripada Katya, perempuan canggih Eropa, ia adalah orang yang udik walau apapun yang telah ditempuhnya untuk ikut menjadi 'canggih'. Adanya oposisi biner antara 'canggih' dan 'udik' merupakan gambaran tentang hal yang superior dan inferior. Secara langsung diungkapkan bahwa yang 'canggih' adalah superior dan yang 'udik' sebagai inferior. 
Dari kutipan-kutipan di atas dapat diidentifikasi bahwa Andrea Hirata yang selalu mengakui dirinya sebagai diri yang inferior, berbeda dengan orang Eropa yang superior. Hal ini adalah suatu identifikasi "othering" dalam travel writing.

\section{Kesimpulan}

Novel Edensor karya Andrea Hiratabanyak menampilkan narasi yang menunjukkan bahwa Andrea Hirata adalah seorang penulis travel writing poskolonial yang banyak menarasikan cerita perjalanannya berdasarkan subjektivitasnya dan informasi secara pribadi terhadap apa yang dialaminya. Pengalaman perjalanan Andrea ditulis dengan gaya yang menyentuh, banyak menggunakan gaya bahasa yang tergambarkan secara signifikan dengan eksplorasi laporan perjalanan kontemporer sebagai latar dan plot, sehingga ia dapat dikategorikan juga sebagai penulis travel writing periode 1914 sampai sekarang.Dengan penggambaran perjalanan yang memasukkan subjektivitas kedalam tulisannya, Andrea Hirata cenderung memberi gambaran dirinya sendiri secara autobiografi dan lebih kepada kesadaran diri (self-consciously) yang ditampilkan dalam setiap perjalanan guna menemukan dirinya.

Dalam identifikasi 'othering', Andrea merupakan orang yang berasal dari Timur dan mengidentifikasikan dirinya sendiri sebagai orang Timur yang udik, tidak terpelajar, tak beradab, dan segala hal yang menujukkan dirinya inferior. Hal ini ditunjukkan ketika tokoh Ikal sebagai self (dirinya) berhadapan dengan other (orangorang Eropa) dan selalu mengakuibahwa dirinya adalah inferior dan mengagumi orang-orang Eropa (other) sebagai bangsa yang superior tanpa ada resistensi sama sekali. Namun lebih dari pada itu, novel ini menunjukkan bahwa dengan mengakui keinferioran dirinya, Andrea Hirata menemukan dirinya sendiri. Sebuah gambaran diri pada sebuah kenyataan yang tidak beradab, tidak terpelajar, dan tidak berkelas(sebagai orang Timur).
Bagaimanapun, sebuah perjalanan dibuat dan dicatatoleh Andrea Hirata sebagai novel yang tidak hanya memberikan gambaran tentang sebuah perjalanan ke tempat-tempat asing, tetapi juga dengan tujuan lainnya, yakni salah satu motivasi perjalanan Ikal yang adalah untuk menemukan wanita yang dicintainya sejak kecil, yaitu A Ling. Hal ini membuat Andrea Hirata dapat dikukuhkan sebagai penulis (dalam travel writing) dengan ciri penulisan Romantic Traveller.

Selanjutnya, Andrea Hirata yang menulis kisah perjalanannya dalam novel Edensor juga memberikan gambaran-gambaran dirinya tersebut untuk dinikmati dan menghibur pembacanya sebagai salah satu ciri dalam tulisan travel writing masa kini.

\section{Daftar Pustaka}

Faruk. 2007. Belenggu Pasca-Kolonial. Yogyakarta: Pustaka Pelajar.

Hirata, Andrea. 2008. Edensor. Yogyakarta: Bentang.

Said, Edward W. 2010. Orientalisme. Yogyakarta: Pustaka Pelajar.

Thompson, Carl. 2011. Travel Writing. London and New York: Routledge.

\section{Sumber Internet}

http://id.wikipedia.org/wiki/Edensor 